\title{
Losing the Life: A Review on Autobiographical Memory in Alzheimer's Disease
}

\section{Hayatı Yitirmek: Alzheimer Hastalığında Otobiyografik Bellek Üzerine Bir Derleme}

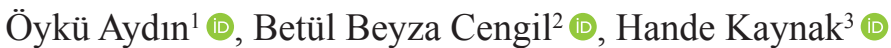

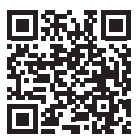

'Psychologist, Graduate Student, Çankaya University, Faculty of Arts and Sciences, Department of Psychology, Ankara, Turkey

${ }^{2}$ Research Assistant, Social Sciences University of Ankara, Faculty of Humanities and Social Sciences, Department of Psychology, Ankara, Turkey

${ }^{3}$ Asst. Prof., Çankaya University, Faculty of Arts and Sciences, Department of Psychology, Ankara, Turkey

ORCID: Ö.A. 0000-0002-0796-8343; B.B.C. 0000-0001-8871-6633; H.K. 0000-0001-8611-5789

\section{Corresponding author/Sorumlu yazar:} Hande Kaynak,

Çankaya University, Faculty of Arts and Sciences, Department of Psychology,

Ankara, Turkey

E-mail/E-posta: handekaynak@gmail.com

Submitted/Başvuru: 08.06.2020

Accepted/Kabul: 14.10.2020

Published Online/Online Yayın: 10.03.2021

Citation/Atıf: Aydin, O., Cengil, B.B., \& Kaynak, H. (2021). Losing the life: A review on autobiographical memory in Alzheimer's disease. Psikoloji Çalışmaları - Studies in Psychology, 41(1): 61-81. https://doi.org/10.26650/SP2020-0081

\begin{abstract}
Alzheimer's disease (AD), the most common type of dementia among older adults, is a progressive and neurodegenerative brain disease. $\mathrm{AD}$ is characterized by progressive memory impairments, but not other types of dementia. Autobiographical memory (AM) is defined as episodes recollected from individuals' life, and it is one of the memory systems impaired in AD. One consequence of $\mathrm{AM}$ decline in $\mathrm{AD}$ is difficulties in the retrieval of recent $\mathrm{AMs}$ rather than past ones. AM contains both episodic and semantic components, and it is crucial for self-concept. The aim of the present study is to review the current understanding of $\mathrm{AM}$ in people with $\mathrm{AD}$. In the introduction part of the review, $\mathrm{AD}$ and its cognitive correlates are presented in detail, with how $\mathrm{AM}$ performance is important for the self. In the second part of the review, AM deteriorations in patients with $\mathrm{AD}$ are discussed. Factors, such as emotion and olfaction, affecting AM are mentioned along with the neural substrates. In this regard, the effect of the emotional dimension (e.g., valence) on the formation and retrieval of AMs is discussed and how AM is studied with olfactory stimuli is presented, respectively. Studies on the link between AM and emotion have shown that there is a positive shift of $A M$ in $A D$, indicating that patients with $\mathrm{AD}$ remember their AMs more positively. In addition, olfactory stimuli evoke more AMs than verbal and visual stimuli. The conclusion section of the current review is devoted to some recommendations that might guide future research. For instance, stage-by-stage investigation of $\mathrm{AM}$ in $\mathrm{AD}$ and the comparison of them in relation to relevant variables could be one way of providing detailed findings on the nature of AM in AD.
\end{abstract}

Keywords: Alzheimer's disease, autobiographical memory, emotion, olfaction 


\section{ÖZ}

Alzheimer hastalığı, progresif ve nörodejeneratif bir beyin hastalığı olup yaşlı yetişkinler arasında en yaygın görülen demans tipidir. Alzheimer hastalı̆̆ı, diğer demans tiplerinin aksine progresif bellek bozulmaları ile karakterizedir. Alzheimer hastalığında görülen bellek bozulmalarından biri olan otobiyografik bellek ise kişinin yaşamı boyunca meydana gelen olayların depolandığı bellek olarak tanımlanır. Alzheimer hastalığında otobiyografik bellek süreçlerinde gözlemlenen düşüşün bir sonucu, geçmiş dönemden ziyade, yakın dönem otobiyografik anıların geri getirilmesinde yaşanan zorluktur. Hem olaysal hem de anlamsal bileşenleri içeren bu bellek tipi, kişinin benlik kavramı için de önemlidir. Bu çalışmanın amacı, Alzheimer hastalarında otobiyografik bellek süreçlerinin güncel alan yazında nasıl ele alındığını incelemektir. Derlemenin giriş kısmında Alzheimer hastalığı ve hastalık ile ilişkilendirilen bilişsel süreçler, otobiyografik bellek performansının benlik için önemiyle birlikte detaylı olarak sunulmuştur. Derlemenin ikinci kısmında Alzheimer hastalarında otobiyografik bellek bozulmaları tartışılmış ve otobiyografik belleğe etki eden duygu ve koku duyusu gibi faktörlerden ilgili nöral yapılar ile birlikte bahsedilmiştir. Bu bağlamda sırasıyla duygusal boyutun (örneğin, değerlik) otobiyografik anıların oluşumu ve geri getirilmesi üzerindeki etkisi tartışılmış ve otobiyografik belleğin koku uyaranlarıyla nasıl çalışıldığı ele alınmıştır. Otobiyografik bellek ve duygu arasındaki ilişki üzerine yapılan çalışmalar, Alzheimer hastalığında otobiyografik anıların içeriğinin olumluya doğru kaydığını, bu kapsamda Alzheimer hastalarının daha olumlu otobiyografik anılarını hatırladıklarını göstermiştir. Ek olarak, koku uyaranlarının sözel ve görsel uyaranlardan daha fazla otobiyografik anı üretmeye neden olduğu bulunmuştur. Mevcut derlemenin sonuç kısmı, gelecek çalışmalara yön verebilecek bazı önerilere ayrılmıştır. Örneğin, Alzheimer hastalığının farklı evrelerinde otobiyografik belleğin incelenmesi ve bellek performansının ilgili değişkenler açısından karşılaştırılması, Alzheimer hastalığında otobiyografik belleğin doğası hakkında ayrıntılı bulgular sağlamanın yollarından biri olabilir.

Anahtar Kelimeler: Alzheimer hastalığı, otobiyografik bellek, duygu, koku duyusu 
Alzheimer's disease (AD), the most common form of dementia, is a critical health condition that may contribute $60-70 \%$ of all the dementia cases (World Health Organization, 2019). Even only in the U.S., more than five million people who are over the age of 65 suffer from AD, the sixth-leading cause of death in the U.S. (Alzheimer's Association, 2020). AD is a progressive neurodegenerative disease that affects memory and other dimensions of cognition, social relationships, emotional processing, and in the end, an individual's sense of self (Grilli, Wank, Bercel, \& Ryan, 2018). It is known that memory performance of patients with $\mathrm{AD}$ is differentiated from healthy individuals (Uçar-Boyraz \& Er, 2007), and some studies claimed that deficits in memory functioning are among the first impairments that occur in AD (Spaan, Raaijmakers, \& Jonker, 2003). Memory impairment involves multiple memory systems such as autobiographical memory (AM), which refers to the recollection of episodes from individuals' life (El Haj, Antoine, Nandrino, \& Kapogiannis, 2015). AM has not only an episodic but also a semantic component. Semantic AM consists of general facts from distinct periods of life, whereas episodic AM contains detailed events that make people experience the same feelings again when they retrieve the memory (Seidl, Lueken, Thomann, Geider, \& Schröder, 2011). AM impairment in patients with AD first shows up with the loss of the episodic part. As AD progresses, patients' sense of self is reduced due to the impaired AM (El Haj et al., 2015; Piolino et al., 2006).

The current review aims to examine the research on AM's nature in $\mathrm{AD}$, provide hints about where this research topic is going, and shed light on future studies based on the research findings. In this direction, in the introduction part of the present review, AD is reviewed in detail first, then the cognitive impairments observed in AD are mentioned. Second, the AM literature is examined, and AM's importance for the sense of self is highlighted. In the review's main body, we give a comprehensive overview of how AM is affected by AD and its neuroanatomical substrates. The review also contributes to the AM literature by examining the role of emotion and olfaction. In this context, a more advanced understanding of these unique variables might be a valuable addition to existing research findings. Finally, the review study contributes to the literature by suggesting research addressing the critical factors in AM. More specifically, research focusing on the lack of episodic detail in this regard can enhance our understanding of $\mathrm{AM}$ in $\mathrm{AD}$. 


\section{Alzheimer's Disease}

$\mathrm{AD}$, the most common cause of dementia, is a progressive, degenerative brain disease (Alzheimer's Association, 2020) associated with aging. The prevalence of AD increases dramatically with age. It is reported that $3 \%$ of people ages $65-74,17 \%$ of people ages $75-84$, and $32 \%$ of people age 85 or older have AD in the U.S. (Hebert, Weuve, Scherr, \& Evans, 2010). In Turkey, approximately 600.000 people have AD, while deaths from AD have increased significantly. The percentage of elderly who died from $\mathrm{AD}$ has risen from 3.9\% in 2014 to $4.6 \%$ in 2018 (Turkish Statistical Institute, 2018).

$\mathrm{AD}$ is characterized by insidious onset, slow and irreversible deterioration in cognitive skills (e.g., memory, language, problem-solving), behavior, functional ability (e.g., activities of everyday life), and mood (Ito et al., 2010). These deteriorations become worse as the disease progresses. Therefore, at the terminal stage of AD most patients lose most of their cognitive skills (Kring, Johnson, Davison, \& Neale, 2012). Even several years before the ultimate diagnosis of $\mathrm{AD}$, cognitive deficits depending on the disease appear when people do not exhibit any noticeable impairment (Small, Fratiglioni, Viitanen, Winblad, \& Bäckman, 2000). AD usually begins with symptoms like absent-mindedness, difficulties in concentration, and memory impairments for recent events and new material (Kring et al., 2012). Language disability, word-finding problems, and disorientation which refers to confusion of identity, time, or place, all accompany the symptoms within a few years (Kring et al., 2012).

Memory decline is one of the main cognitive hallmarks of AD (El Haj et al., 2015). The disease starts with memory complaints, which may affect episodic memory, visual orientation, and speech production (Jahn, 2013). There is a progressive memory decline due to AD. During the early course of AD, long-term explicit memory (consisting of the semantic and episodic memory) and working memory are affected (Jahn, 2013). Semantic memory is a system to receive, retain, and transmit information about words, their meanings, and the classification of concepts. In contrast, episodic memory is a system that collects and stores information about temporally dated events in terms of autobiographical reference (Tulving, 1972). Deteriorations in the preclinical stage of AD start with a decline in episodic memory (Can \& Karakaş, 2005). Episodic memory decline is basically caused by problems in encoding the newly learned materials (Öktem, 2003). Accordingly, patients with $\mathrm{AD}$ are not able to learn new material, and repeated trials for 
learning cannot enhance learning (Öktem, 2003). Even though episodic memory decline is more apparent, semantic memory decline may also occur when investigated in detail at the early stages of AD (Binetti et al., 1996; Karakaş \& İrkeç, 2003). These patients show a decline in their ability to use semantic strategies and cues in processing information to remember (Karakaş \& İrkeç, 2003; Öktem, 2003). In contrast, Can, İrkeç, and Karakaş (2006) stated that semantic memory decline is seen in the advanced stages of AD. On the other hand, in the middle stage of the disease, visual memory, immediate and delayed recall performance is declined (Can et al., 2006). In the late stages of the disease, these declines become worse, and deteriorations in short-term memory and semantic memory are also detected (Can et al., 2006). Additionally, it is known that explicit memory, which consists of semantic and episodic memory, is impaired in the early stages of $\mathrm{AD}$, whereas there are conflicting results about implicit memory (Can \& Karakaş, 2005). Most of the studies indicated that implicit memory is impaired in AD (Fleischman \& Gabrieli, 1999). On the other hand, other studies suggest that implicit memory is preserved in AD (Akdemir, Cangöz, Örsel, \& Selekler, 2007; Machado et al., 2009).

$\mathrm{AD}$ is also considered to be related to the inability to retrieve specific memories and a reduced sense of self (El Haj \& Antoine, 2017; Morris \& Mograbi, 2013). Hence, AM, which is defined as memories for personal experiences (Conway, 2005), was found to be compromised in patients with AD. In the following section, the link between AM and the self is evaluated.

\section{Autobiographical Memory and the Self}

AM represents one's experiences by collecting events and facts from the past (Moses, Culpin, Lowe, \& McWilliam, 2004; Seidl et al., 2011). AM consists of semantic and episodic memory. Semantic memory (also called personal semantic memories) contains information, and facts from different lifetime periods related to a person's life (Ivanoiu, Cooper, Shanks, \& Venneri, 2006; Tulving, 1999) and does not include any contextual detail (Tulving, 1972). On the other hand, episodic memories (also called personal episodic memories) are personally experienced singular events that happened at a specific place and time, and rich in terms of details including emotions (Barnabe, Whitehead, Pilon, Arsenault-Lapierre, \& Chertkow, 2012; El Haj et al., 2015; Martinelli, Anssens, Sperduti, \& Piolino, 2013). Because of these features, recalling episodic memories allows people to re-experience that event (travel in time mentally) which re- 
quires an integration of a number of subsystems (e.g., emotion, sensory information, etc.) (Holland \& Kensinger, 2010; Meulenbroek, Rijpkema, Kessels, Rikkert, \& Fernández, 2010; Seidl et al., 2011; Tulving, 2002). Semantic memory does not rely on a specific event; so, recalling it does not wake re-experience. Instead, it produces a feeling of knowing (Holland \& Kensinger, 2010). This distinction between episodic and semantic memory is also observed by the remember/know paradigm. If the person remembers, that means the person retrieves a specific memory with its contextual details and mentally places him/herself in that event. On the other hand, if the person knows, that means there is only factual knowledge without any contextual detail, and the person only knows the event occurred (El Haj et al., 2015; Prebble, Addis, \& Tippett, 2013; Tulving, 1985). Remember refers to autonoetic consciousness, which is correlated with episodic memory, and know refers to noetic consciousness which characterizes semantic memory (Tulving, 1985).

Except for these features, there is one conspicuous aspect of AM. Conway and Pleydell-Pearce (2000) proposed that AM is constructed within a self-memory system (SMS), which contains broad areas of autobiographical knowledge at three different levels of specificity in a hierarchy: lifetime periods, general events, and event-specific knowledge (Conway \& Pleydell-Pearce, 2000). Lifetime periods cover general knowledge about different aspects of our lives, whereas general events are more specific than lifetime periods, and they can include both repeated events and single events (Barsalou, 1988; Conway \& Pleydell-Pearce, 2000). On the other hand, event-specific knowledge contains distinct perceptual and sensory details (Holland \& Kensinger, 2010). According to this proposed memory system, these autobiographical memories at distinct levels of specificity are organized in a hierarchy that are interlinked and are defined as part of personal past. The SMS also contains current goals of the working self, which modulate the construction of memories. The working self influences both the encoding and retrieval of AMs. Since patients with AD often show deterioration in maintenance of the self, investigations of AM have grown in recent studies.

AM has fundamental importance for the self (Conway \& Pleydell-Pearce, 2000). It helps the self to develop as well as restrain what we can become (Williams \& Conway, 2009). In other words, AM shapes an individual's self-concept and guides the self for future behavior (Hou, Miller, \& Kramer, 2005). Additionally, it serves as a foundation for self-knowledge, self-consciousness, and self-images (El Haj et al., 2015). Develop- 
ment of the self is seen in the lifespan retrieval curve, also known as temporal distribution (Conway, 2005; El Haj et al., 2015). If a participant is asked to freely recall any event from his/her life and to state the date for each event, a lifespan retrieval curve is observed. This distribution consists of three different features: childhood amnesia, the reminiscence bump, and the recency effect. Childhood amnesia covers the times from birth to approximately five years of age (Conway, 2005), and it simply refers to the disappearance of our memories from that period of life. The reminiscence bump is the period between ages 10 to 30 (Conway \& Pleydell-Pearce, 2000). In this period of our life, there is a meaningful increase in our memories. The last component of the curve, which is recency, is the time from the reminiscence bump to present, and basically, we remember memories mostly from recent years (Conway, 2005). These memories not only distinguish as a timeline but also differentiate from each other in characteristics they have. In the study by Ece, Demiray, Öner, and Gülgöz (2019), participants were asked to recall three types of AMs: The earliest childhood memory, a very recent memory, and a free-report memory. Then participants rated all their memories in terms of their characteristics of emotionality, confidence, importance, rehearsal frequency, and vividness. According to the results of ratings of the memory characteristics, earliest memories had lower scores than recent memories in vividness, confidence, and rehearsal frequency characteristics, while they were similar to recent memories in terms of emotionality and importance (Ece et al., 2019). This suggests that earliest memories are not particularly unique.

One intriguing case about the importance of the self in AM is Henry, a patient with mild cognitive impairment due to AD. In their study, Philippi et al. (2017) compared Henry's cognitive performance with a group of AD patients as well as healthy controls. Results demonstrated that although AD patients produced some AM, Henry was not only incapable of producing any personal memories, but also despite his high educational level, he could not define his self-concept (Philippi et al., 2017). In other words, he could not produce any "I am..." statements in a Twenty Statements Test in which participants were told to answer the question "Who I am?". Furthermore, he was not aware of his deficiency in AM. Henry was an exceptional case, yet AM distortion in AD could be the reason for the reduced sense of self. Difficulties in retrieval and failures in the consolidation of new materials related to self-ability in AD patients seem to be secondary to loss of AM (Morris \& Mograbi, 2013). 


\section{Autobiographical Memory in Alzheimer's Disease}

One of the defining clinical features of AD is AM compromise (El Haj, Gandolphe, Gallouj, Kapogiannis, \& Antoine, 2017). Even in prodromal stages (Irish, Lawlor, O'mara, \& Coen, 2010; Leyhe, Müller, Millian, Eschweiler, \& Saur, 2009) and early diagnostic stages of AD (Hou et al., 2005; Ivanoiu, Cooper, Shanks, \& Venneri, 2004) consequential evidence for AM decline is indicated. In the early stages of the disease, with the decline of AM, the specificity of the memories is also reduced (Morris \& Mograbi, 2013). As a result of a decline in autobiographical specificity in AD, memories are de-contextualized, and the ability for mentally reliving past events shifts to a general sense of familiarity (El Haj et al., 2020). This idea is argued in the Autobiographical Memory in Alzheimer's Disease (AMAD) model. In the context of the AMAD model, the autobiographical deficit is characterized by episodic decrease, a decline in personal experience and anterograde and retrograde amnesia (El Haj et al., 2015). In the patients with $\mathrm{AD}$, having these deficits limits their access to memories, which form self-images, self-consciousness, and self-knowledge. Consequently, the patient's sense of identity is reduced (El Haj \& Antoine, 2017; El Haj et al., 2015).

Episodic AM is considered one of the cognitive components that appears in the last periods of development, and it is the first component to be lost with normal aging (Piolino et al., 2006), and in diseases such as AD (Morris \& Mograbi, 2013). In normal aging, episodic AM impairment is observed (Bruno et al., 2020). Considering autobiographical recall, research has indicated a decline in access to specific episodic detail with cognitive aging, while there is no decline in access to other non episodic or semantic information (Levine, Svoboda, Hay, \& Winocur, 2002). Particularly, young adults' memories include more specific episodic details than memories of healthy older adults (Levine et al., 2002). This kind of episodic AM impairment appears to be worse in AD patients when compared with healthy elderly controls (Barnabe et al., 2012; Hou et al., 2005). Bearing the characteristics of $\mathrm{AM}$ compromise in $\mathrm{AD}$ in mind, the major characteristic is the decline in specificity (i.e., overgenerality). Overgenerality refers to an inability to produce specific memories that occurred at a distinct place and time (El Haj et al., 2017; Morris \& Mograbi, 2013; Moses et al., 2004). Problems in retrieving AMs in patients with AD have been related to a low personal experience of memories, with a reduced ability to mentally travel back in personal time (El Haj et al., 2015). Another difference between healthy older adults and AD patients is that while healthy older adults have deficits in 
retrieving AMs episodic details, patients with $\mathrm{AD}$ also experience problems in encoding processes (Öktem, 2003), leading to greater episodic AM decline.

When studies on AM performance of patients with AD are examined, it is remarkable to note that some studies prefer to use interviews as an assessment tool. One of the interviews to assess AM is Autobiographical Memory Interview (AMI) (Kopelman, Wilson, \& Baddeley, 1989), which consists of questions on personal-semantic memories and autobiographical events. Questions on personal-semantic memories examine facts from past life, related to background information (e.g., date of birth), childhood (e.g., address), early adulthood (e.g., date of the wedding day) and more recent events (e.g., holidays in last year) (Kopelman et al., 1989). On the other hand, questions about the autobiographical events consist of items which assess three periods of life: Childhood (e.g., first memory), early adulthood (e.g., first day at a job) and recent period (e.g., news about a relative) (Kopelman et al., 1989). Studies in which AMI is used to assess $\mathrm{AM}$ performance in patients with $\mathrm{AD}$ demonstrated that patients with $\mathrm{AD}$ exhibit impairments in both autobiographical events and personal-semantic memories (Addis \& Tippett, 2004; Hou et al., 2005; Meeter, Eijsackers, \& Mulder, 2006; Seidl et al., 2011). For instance, the results of the study conducted by Hou et al. (2005) showed that AD patients had more problems than controls in recalling autobiographical events and personal semantic memories from recent time periods. Similarly, Meeter et al. (2006) found that patients with mild or moderate AD recalled significantly fewer AMs than their spouses.

Autobiographical Interview (AI) is another tool for evaluating participants' autobiographical memories. In the interview, participants are asked to select one event for each five different lifetime periods (early childhood, adolescent-teenage years, early adulthood, middle age, and the previous year) of their lives (Levine et al., 2002). There is also an optional list that contains 100 typical life events to help the retrieval process of the participants who want some cues. Participants must be part of each event, and it should not be an event heard from someone else. Moreover, these events should include a specific time and place, and the participant should give detail as much as possible. In scoring of AI, researchers are interested in the numbers of internal and external details as well as some other categories which take scores between 0 and 3 . The difference between the number of internal and external details also indicates how specific memory is. Internal details include time, place, thoughts/emotions, perception, and event, whereas 
external details include semantic information or repetition (Levine et al., 2002). Therefore, if a memory is rich in internal details, the memory also contains specific knowledge. In a study conducted with older adults who are at risk of AD ( $\varepsilon 4$ carriers), AI was administered, and the results demonstrated that carriers' memories contained little internal detail (Grilli et al., 2018). In other words, even those at risk for AD showed a decline in specificity (Grilli et al., 2018).

Episodic memories are emotionally laden part of autobiographical memories. Since there is a decline in episodic AM in AD patients, the role of emotion on AMs of AD patients is worth investigating. Besides, even though AD patients show deterioration in odor identification as the disease progresses, recent studies suggest that olfactory stimuli effectively evoke AMs in patients with AD. That is why we sought to consider these specific variables in the content of the present review. In the following sections, how AM is studied with emotional and olfactory stimuli in people with AD is presented, respectively. Then, AD-related brain imaging studies are evaluated to understand better the neural basis of AM deficits in AD patients.

\section{Emotion}

As much as emotion is crucial for retrieval of AM, it also has a fundamental significance for emotions (Berntsen \& Rubin, 2002; Conway \& Pleydell-Pearce, 2000; Öner \& Gülgöz, 2017). In this regard, it would be of interest to emphasize some theoretical assumptions about the effect of emotion on AM in people with AD. Especially the episodic component of AMs is more emotionally loaded than semantic component, therefore in the retrieval of episodic AMs, emotional experiences are salient (Irish et al., 2011; Martinelli et al., 2013; Piefke, Weiss, Zilles, Markowitsch, \& Fink, 2003). Further, emotional AMs are a key component of a person's emotional well-being (El Haj et al., 2020).

In the studies which used the AI or its manual, emotion/thought is one of the internal details and scoring criteria. Therefore, these studies can record how much emotional detail participants have in their AMs. For instance, a study in which they used the AI, they found that AMs of patients with AD were lacking emotional detail (Irish et al., 2011). The researchers indicated that $A D$ patients showed deficits in the recent $A M$, and due to the impairments in emotional processing, the disruption in recalling emotional AMs were observed. 
In a study by El Haj et al. (2020), the researchers investigated the emotion regulation strategies in AD patients. In this study, they asked participants, who were a group of AD patients and control, to retrieve memories related to the cues sad and happy words. After the retrieval part, they asked participants to rate their memories on a seven-point scale in terms of emotional valence at retrieval time and at the first time they encoded (El Haj et al., 2020). It turned out that participants (both AD and the control group) rated their happy memories more positively when they retrieved compared to the time they encoded. The same trend appeared in sad memories as well. They rated the sad events less negatively when they retrieved compared to the time they encoded (El Haj et al., 2020). In other words, $\mathrm{AD}$ patients showed cognitive reappraisal by re-interpreting their memories' meaning and by changing these memories' emotional influence (El Haj et al., 2020). To sum up, AD patients had a decreased specificity, yet they still exhibited emotional regulation. As El Haj et al. (2020) explained, AD patients gain strengths from both negative and positive memories and use these strengths to cope with the stressors. In another study, researchers asked three groups (AD patients, healthy older adults, and young adults) of participants to recall events related to autobiographical episodes, personal semantics, and self-defining memory (Martinelli et al., 2013). After researchers recorded all the memories, they also calculated the percentage of positive ones. Results demonstrated that $\mathrm{AD}$ patients and older adults recalled more positive personal semantics compared with young adults and other AM types (Martinelli et al., 2013). These findings can be interpreted as a positivity bias observed in healthy aging and AD.

Emotion is a variable that should be considered and investigated more in the studies of $\mathrm{AM}$ in AD. Emotion could be the context of the memory, as mentioned before, or the response to a memory. Berntsen (2010) suggested that involuntary memories are accompanied by a stronger emotional reaction compared to voluntary memories. Likewise, emotion could be triggered by odor-evoked AMs (El Haj et al., 2017; Herz, 2004; Herz, Eliassen, Beland, \& Souza, 2004; Rubin, Groth, \& Goldsmith, 1984).

\section{Olfaction}

Even though memory researchers are comprehensively focused on AM, most of the present evidence is based upon verbal cueing, and evidence on effects of other types of cues on retrieving personal events is sparse (Larsson \& Willander, 2009). Still, there are studies that investigated the effects of different types of cues on AM. Previous studies stated that olfactory cues activate memories from the past (Willander \& Larsson, 2006), 
and memories retrieved in return for olfactory cues are associated with a greater sense of being taken back in time, compared to verbal and visual cues (Cady, Harris, \& Knappenberger, 2008; Willander \& Larsson, 2006). It is also stated that odors are efficient cues to evoke AM (Larsson \& Willander, 2009). Particularly impaired odor identification and generally olfactory dysfunction is known in patients with AD (Velayudhan, 2015). Despite the advantages of olfactory cueing in AM research, it may be less optimal for patients with AD because of impaired odor identification (Velayudhan, 2015). This may be the reason why there is a limited number of studies examining the effects of olfactory cueing on AM in AD. These studies were evaluated in the following part.

Some studies conducted with AD patients have investigated the effects of odor exposure on AM performance. For instance, in a study by El Haj et al. (2017), patients with mild $\mathrm{AD}$ and healthy controls were required to retrieve two personal memories after music exposure, after odor exposure, and in an odor-and-music free (control) condition. Results indicated that in the odor exposure condition, patients with mild AD showed better emotional experience, specificity, retrieval time, and mental time travel than the control condition (El Haj et al., 2017). It is also pointed out that at least in the mild stage of the disease, olfactory cueing may be a valid and useful tool to promote AM (E1 Haj et al., 2017). Similarly, Glachet, Gandolphe, Gallouj, Antoine, and El Haj (2018) reported the positive effect of odor exposure on $\mathrm{AM}$ in $\mathrm{AD}$. In the study, mild AD patients were asked to retrieve AMs after the exposure to odor, without odor, and in the control condition (Glachet et al., 2018). Results showed that odor-evoked AMs were more specific, and these memories were accompanied by more personal experiences in patients with AD (Glachet et al., 2018). In another study conducted by Glachet, Moustafa, Gallouj, and El Haj (2019), patients with mild AD were required to recount incidents from their childhood, adulthood, and recent period in with and without odor conditions to investigate how odor exposure suppressed retrograde, and anterograde amnesia while considering the ability of mild AD patients to retrieve few remote or recent memories (Glachet et al., 2019). Findings revealed that patients with AD produced a more specific and higher number of recent, adulthood, and childhood memories in the odor exposure condition compared to without odor condition (Glachet et al., 2019). These findings suggest that odors are a strong cue to stimulate the retrieval of AMs in individuals with AD. 


\section{Neuroanatomical Substrates of AM in people with AD}

Memory decline is one of the main cognitive deficits in AD and tends to differ in terms of the age of the memories according to neurodegeneration due to the disease (Kirk \& Berntsen, 2018). In the early stages of AD, a decline in recalling recent personal memories is stunning (Irish et al., 2018). Some studies have supported that recent incidents are less accessible than past ones in dementias, including early stages of $\mathrm{AD}$ (Barnabe et al., 2012; De Simone et al., 2016; Leyhe et al., 2009; Piolino et al., 2003). This deficit in memory usually is caused by medial temporal lobe (MTL) atrophy, which arises in the entorhinal cortex and spreads to neocortical sites through the hippocampus (Gilboa et al., 2005; Irish et al., 2018; Philippi et al., 2012). Glachet et al. (2019) also supported these results and found that neurodegeneration in MTL, especially in the hippocampus, may be associated with memory decline in AD. Additionally, in a study conducted with AD patients indicated that patients' hippocampus was smaller than healthy elderly (Meulenbroek et al., 2010).

Impaired brain areas due to progressive brain degeneration in $\mathrm{AD}$ overlap with the substrates associated with AM. The neuroanatomical constructs of AM are the medial and lateral temporal cortices, including the hippocampus; medial and ventrolateral prefrontal cortices; posterior cingulate cortex; temporoparietal junction and cerebellum (Meulenbroek et al., 2010; Müller et al., 2012; Svoboda, McKinnon, \& Levine, 2006). In addition to these regions, activations in occipital association areas are recorded during the retrieval of episodic AMs (Cabeza \& St Jacques, 2007; Meulenbroek et al., 2010). Moreover, it is stated that from two routes of autobiographical recall, voluntary and involuntary, voluntary AM retrieval engages more prefrontal regions than in involuntary AM retrieval (Addis, Knapp, Roberts, \& Schacter, 2012; Kirk \& Berntsen, 2018).

In the previous studies, it is indicated that while the hippocampus has a main role in retrieving AMs (Svoboda et al., 2006), relying on other structures, namely amygdala (Philippi et al., 2015) for the enrichment of memories with emotions is also considered. Basically, the amygdala is activated during the phases of encoding and consolidation for emotional pictures (Dolcos, LaBar, \& Cabeza, 2004), in the retrieval for both autobiographical recall routes (Buchanan, 2007), and even in the presentation of laboratory-based stimuli (Smith, Henson, Rugg, \& Dolan, 2005). Nonetheless, the amygdala and other limbic structures, which are related to emotional and memory processes are impaired in the early stages of AD (Braak \& Braak, 1991). Still, there is limited knowl- 
edge about emotional AM in AD patients and its relationship with limbic structure volume (Philippi et al., 2015). Studies focusing on the olfaction and memory relation from a neuroanatomical perspective indicated that odors are related to the limbic system as the amygdala is located just one synapse away from olfactory receptors (Larsson, Willander, Karlsson, \& Arshamian, 2014). Besides, memories evoked by olfactory stimuli have been associated with the activation in hippocampal regions and the amygdala (Arshamian et al., 2013). This is due to the fact that the neuropathological processes of AD often target these certain brain regions preferentially (Pennanen et al., 2004).

Grey matter atrophy progression in AD patients appears to affect brain areas associated with AM (Müller et al., 2012). This atrophy causes cortical thinning, mainly in lateral temporal brain regions, hence, decreases performance in AM. There is a rigid association between grey matter volumes in the hippocampus, and the ability of the patients to retrieve the most recent but not the remote AMs in both aspects of episodic and semantic (Serra et al., 2020). Damage in the bilateral anterior temporal poles affects recent memory performance, whereas the right inferior and middle temporal cortices affect remote memory performance (Irish et al., 2018). A study conducted by Gilboa et al. (2005) with AD patients found that the amount of tissue damage in MTL and anterior temporal neocortex constructs is strongly associated with the content of deficit in memory for autobiographical events (Gilboa et al., 2005). In the same study, they also found that tissue loss of the lateral temporal cortex (especially the anterior aspect) is related to memory loss for personal events and personal semantics (Gilboa et al., 2005). Besides, it is stated that personal events are mostly associated with the right side, while personal semantics are mostly associated with the left side of MTL (Gilboa et al., 2005).

\section{DISCUSSION}

It is known that memory decline with aging is a component of the normal process of development. With normal aging, many people develop some cognitive impairments; more specifically, studies report impaired performance on AM tests (Bruno et al., 2020; Piolino et al., 2006). While young adults' AMs consist of both semantic and episodic details, in older adults AMs mostly include semantic details, and a substantial decline in episodic details occurs (Levine et al., 2002). Studies suggest a significant shift from episodic to semantic in AMs of healthy older adults (Levine et al., 2002). This shift becomes worse in people who have $\mathrm{AD}$, which is commonly seen among older adults and 
attacks the memory system (Barnabe et al., 2012; Hou et al., 2005). In addition to healthy older adults' problems in the retrieval of episodic details, patients with $\mathrm{AD}$ also have difficulties in encoding episodic memories (Öktem, 2003). Several researches addressed these issues to investigate the differences in AM performance between AD patients and healthy older control groups regarding emotional and olfactory stimuli (El Haj et al., 2017; Irish et al., 2011; Martinelli et al., 2013; Velayudhan, 2015). In this direction, the aim of the current review is to examine the research on AM's nature in $\mathrm{AD}$ and shed light on future research on AM in AD. In particular, the current review aims to investigate how $\mathrm{AM}$ is affected by $\mathrm{AD}$, the role of emotion and olfaction, and neuroanatomical substrates, respectively.

As discussed in previous sections, $\mathrm{AD}$ is mainly characterized by memory deficits. In $\mathrm{AD}$, patients generally experience more difficulties in remembering recent events than past ones (Kring et al., 2012). Considering the other characteristics of AM in AD, it is clear that patients with $\mathrm{AD}$ retrieve AMs with less specificity, which is termed as overgenerality (El Haj et al., 2020; Morris \& Mograbi, 2013). To assess AM performance in patients with $\mathrm{AD}$, researchers mainly use two interviews, namely AMI and AI (Kopelman et al., 1989; Levine et al., 2002). When the relevant literature was examined, there were two remarkable variables, which are emotion and olfaction, mostly studied in $\mathrm{AM}$ in $\mathrm{AD}$. In the emotion literature, it is highlighted that even if AMs do not always contain enough emotional detail (Irish et al., 2011), they still have positive content, and patients with $\mathrm{AD}$ also remember their AMs more positively (Martinelli et al., 2013). On the other hand, olfactory stimuli evoke more memories than verbal and visual stimuli in patients with AD (El Haj et al., 2017; Glachet et al., 2018). In the neuroanatomical perspective, most of the damage in $\mathrm{AD}$ appears in temporal areas, especially in hippocampal regions, which play a central role in the formation and retrieval of AM (Glachet et al., 2019; Meulenbroek et al., 2010; Serra et al., 2020).

Although these studies support each other, there is still little known about AM in terms of different variables in $\mathrm{AD}$. In light of previous research, we listed some recommendations for future work. First, investigating AM in AD stage by stage and comparing them in terms of relevant variables might be efficient ways to provide precise results about the nature of $\mathrm{AM}$ in $\mathrm{AD}$. It is well-known that $\mathrm{AD}$ is a progressive disease, and death rates have risen significantly during the last years. Therefore, comparisons across the stages of the disease can reveal additional variables related to AM deficits. Second, 
to our knowledge, no prior studies have examined the accuracy of the AMs retrieved by AD patients. Studying false memory, in this sense, could be enlightening about the progressive nature of the disease. Additionally, using AM performance on early detection of $\mathrm{AD}$ is pointed out in a study conducted by Grilli et al. (2018). Their findings support the idea that lack of episodic detail in AMs may be a signal of future cognitive deficiencies related to AD (Grilli et al., 2018). This assumption might be addressed in future studies. The study of Grilli et al. (2018) was cross-sectional in nature. Longitudinal data for future research might extend their explanations.

Peer-review: Externally peer-reviewed.

Conflict of Interest: The authors have no conflict of interest to declare.

Grant Support: The authors declared that this study has received no financial support.

Hakem Değerlendirmesi: Dış bağımsız.

Çıkar Çatışması: Yazarlar çıkar çatışması bildirmemiştir.

Finansal Destek: Yazarlar bu çalışma için finansal destek almadığını beyan etmiştir.

\section{References/Kaynakça}

Addis, D. R., Knapp, K., Roberts, R. P., \& Schacter, D. L. (2012). Routes to the past: Neural substrates of direct and generative autobiographical memory retrieval. Neuroimage, 59(3), 2908-2922. doi: 10.1016/j.neuroimage.2011.09.066

Addis, D. R., \& Tippett, L. (2004). Memory of myself: Autobiographical memory and identity in Alzheimer's disease. Memory, 12(1), 56-74. doi: 10.1080/09658210244000423

Akdemir, A., Cangöz, B., Örsel, S., \& Selekler, K. (2007). Hafif kognitif bozukluğu olan hastalarla Alzheimer tipi demans hastalarının örtük bellek performansı açısından karşılaştırılması [A comparison of implicit memory performance in mild cognitive impairment and Alzheimer type dementia patients]. Turkish Journal of Psychiatry, 18(2), 118-128.

Alzheimer's Association. (2020). 2020 Alzheimer's disease facts and figures. Alzheimer's \& Dementia, 16(3), 391-460. doi: 10.1002/alz.12068

Arshamian, A., Iannilli, E., Gerber, J. C., Willander, J., Persson, J., Seo, H. -S., Hummel, T., \& Larsson, M. (2013). The functional neuroanatomy of odor evoked autobiographical memories cued by odors and words. Neuropsychologia, 1, 123-131. doi: 10.1016/j.neuropsychologia.2012.10.023

Barnabe, A., Whitehead, V., Pilon, R., Arsenault-Lapierre, G., \& Chertkow, H. (2012). Autobiographical memory in mild cognitive impairment and Alzheimer's disease: A comparison between the Levine and Kopelman interview methodologies. Hippocampus, 22, 1809-1825.

Barsalou, L. W. (1988). The content and organization of autobiographical memories. In U. Neisser \& E. Winograd (Eds.), Remembering reconsidered: Ecological and traditional approaches to the study of memory (pp. 193-243). Cambridge: Cambridge University Press. doi: 10.1017/ CBO9780511664014.009

Berntsen, D. (2010). The unbidden past: Involuntary autobiographical memories as a basic mode of remembering. Current Directions in Psychological Science, 19(3), 138-142. doi: $10.1177 / 0963721410370301$ 
Berntsen, D., \& Rubin, D. C. (2002). Emotionally charged autobiographical memories across lifespan: The recall of happy, sad, traumatic and involuntary memories. Psychology of Aging, 17(4), 636352. doi: 10.1037/0882-7974.17.4.636

Binetti, G., Cappa, S. F., Magni, E., Padovani, A., Bianchetti, A., \& Trabucchi, M. (1996). Disorders of visual and spatial perception in the early stage of Alzheimer's disease. Annals New York Academy of Sciences, 777, 221-225. doi: 10.1111/j.1749-6632.1996.tb34422.x

Braak, H., \& Braak, E. (1991). Neuropathological stageing of Alzheimer-related changes. Acta Neuropathologica, 82, 239-259.

Bruno, D., Suppicich, F., Schurmann-Vignaga, S., Klein, A., Aiskovich, M., Torralva, T., Manes, F., Pontello, N., \& Roca, M. (2020). Cognitive stimulation of autobiographic and emotional memory in a patient with Alzheimer's disease. Journal of Psychiatry and Psychology Research, 4(1), 210-218.

Buchanan, T. W. (2007). Retrieval of emotional memories. Psychological Bulletin, 133(5), 761-779. doi: 10.1037/0033-2909.133.5.761

Cabeza, R., \& St Jacques, P. (2007). Functional neuroimaging of autobiographical memory. Trends in Cognitive Sciences, 11(5), 219-227. doi: 10.1016/j.tics.2007.02.005

Cady, E. T., Harris, R. J., \& Knappenberger, J. B. (2008). Using music to cue autobiographical memories of different lifetime periods. Psychology of Music, 36, 157-178. doi: 10.1177/0305735607085010.

Can, H., İrkeç, C., \& Karakaş, S. (2006). Alzheimer tipi demansın farklı evrelerinin nöropsikolojik profili [Neuropsychological profile of different stages of dementia of Alzheimer's type]. New Symposium Journal, 44(3), 115-135.

Can, H., \& Karakaş, S. (2005). Bilişsel süreçlerde Alzheimer tipi demansa bağlı değişiklikler [Dementia of Alzheimer type-related changes in cognitive processes]. Journal of Clinical Psychiatry, 8, 37-47.

Conway, M. A. (2005). Memory and the self. Journal of Memory and Language, 53, 594-628. doi: 10.1016/j.jml.2005.08.005

Conway, M. A., \& Pleydell-Pearce, C. W. (2000). The construction of autobiographical memories in the self-memory system. Psychological Review, 107(2), 261-288. doi: 10.1037/0033-295X.107.2.261

De Simone, M. S., Fadda, L., Perri, R., Aloisi, M., Caltagirone, C., \& Carlesimo, G. A. (2016). Does retrieval frequency account for the pattern of autobiographical memory loss in early Alzheimer's disease patients? Neuropsychologia, 80, 194-200. doi: 10.1016/j.neuropsychologia.2015.11.024

Dolcos, F., LaBar, K. S., \& Cabeza, R. (2004). Interaction between the amygdala and the medial temporal lobe memory system predicts better memory for emotional events. Neuron, 42, 855-863.

Ece, B., Demiray, B., Öner, S., \& Gülgöz, S. (2019). Comparison of earliest and later autobiographical memories in young and middle-aged adults. Studies in Psychology, 39(1), 45-78. doi: 10.26650/ SP2018-0037

El Haj, M., \& Antoine, P. (2017). Describe yourself to improve your autobiographical memory: A study in Alzheimer's disease. Cortex, 88, 165-172. doi: 10.1016/j.cortex.2017.01.004

El Haj, M., Antoine, P., Nandrino, J. L., \& Kapogiannis, D. (2015). Autobiographical memory decline in Alzheimer' disease, a theoretical and clinical overview. Ageing Research Reviews, 23, 183-192. doi: 10.1016/j.arr.2015.07.001

El Haj, M., Boudoukha, A., Moustafa, A. A., Antoine, P., Allain, P., \& Gallouj, K. (2020). "La vie en rose": A positive shift of autobiographical memory in Alzheimer's disease. Archives of Gerontology and Geriatrics, 86, 1-7. doi: 10.1016/j.archger.2019.103953

El Haj, M., Gandolphe, M. C., Gallouj, K., Kapogiannis, D., \& Antoine, P. (2017). From nose to memory: The involuntary nature of odor-evoked autobiographical memories in Alzheimer's disease. Chemical Senses, 43(1), 27-34. doi: 10.1093/chemse/bjx064 
Fleischman, D. A., \& Gabrieli, J. D. (1999). Long term memory in Alzheimer's disease. Current Opinion in Neurobiology, 9(2), 240-244. doi: 10.1016/S0959-4388(99)80034-8

Gilboa, A., Ramirez, J., Köhler, S., Westmacott, R., Black, S. E., \& Moscovitch, M. (2005). Retrieval of autobiographical memory in Alzheimer's disease: Relation to volumes of medial temporal lobe and other structures. Hippocampus, 15(4), 535-550. doi: 10.1002/hipo.20090

Glachet, O., Gandolphe, M. C., Gallouj, K., Antoine, P., \& El Haj, M. (2018). Effects of olfactory stimulation on autobiographical memory in Alzheimer's disease. Geriatrie et Psychologie Neuropsychiatrie du Vieillissement, 16(3), 311-320. doi: 10.1684/pnv.2018.0748

Glachet, O., Moustafa, A. A., Gallouj, K., \& El Haj, M. (2019). Smell your memories: Positive effect of odor exposure on recent and remote autobiographical memories in Alzheimer's disease. Journal of Clinical and Experimental Neuropsychology, 41(6), 555-564. doi: 10.1080/13803395.2019.1586840

Grilli, M. D., Wank, A. A., Bercel, J. J., \& Ryan, L. (2018). Evidence for reduced autobiographical memory episodic specificity in cognitively normal middle-aged and older individuals at increased risk for Alzheimer's disease dementia. Journal of the International Neuropsychological Society, 24(10), 1073-1083. doi: 10.1017/S1355617718000577

Hebert, L. E., Weuve, J., Scherr, P. A., \& Evans, D. A. (2010). Alzheimer disease in the United States (2010-2050) estimated using the 2010 census. Neurology, 80(19), 1778-1783. doi: 10.1212/ WNL.0b013e31828726f5

Herz, R. (2004). A naturalistic analysis of autobiographical memories triggered by olfactory visual and auditory stimuli. Chemical Senses, 39(3), 217-224. doi: 10.1093/chemse/bjh025

Herz, R. S., Eliassen, J., Beland, S., \& Souza, T. (2004). Neuroimaging evidence for emotional potency of odor-evoked memory. Neuropsychologia, 42(3), 371-378. doi: 10.1016/j. neuropsychologia.2003.08.009

Holland, A. C., \& Kensinger, E. A. (2010). Emotion and autobiographical memory. Physics of Life Reviews, 7, 88-131. doi: 10.1016/j.plrv.2010.01.006

Hou, C. E., Miller, B. L., \& Kramer, J. H. (2005). Patterns of autobiographical memory loss in dementia. International Journal of Geriatric Psychiatry, 20, 809-815. doi: 10.1002/gps.1361

Irish, M., Hornberger, M., Lah, S., Miller, L., Pengas, G., Nestor, P. J., Hodges, J. R., \& Piguet, O. (2011). Profiles of recent autobiographical memory retrieval in semantic dementia, behavioralvariant frontotemporal dementia, and Alzheimer's disease. Neuropsychologia, 49, 2694-2702. doi: 10.1016/j.neuropsychologia.2011.05.017

Irish, M., Landin-Romero, R., Mothakunnel, A., Ramanan, S., Hsieh, S., Hodges, J. R., \& Piguet, O. (2018). Evolution of autobiographical memory impairments in Alzheimer's disease and frontotemporal dementia - A longitudinal neuroimaging study. Neuropsychologia, 110, 14-25. doi: 10.1016/j.neuropsychologia.2017.03.014

Irish, M., Lawlor, B. A., O'mara, S. M., \& Coen, R. F. (2010). Exploring the recollective experience during autobiographical memory retrieval in amnestic mild cognitive impairment. Journal of the International Neuropsychological Society, 16, 546-555. doi: 10.1017/S1355617710000172

Ito, K., Ahadieh, S., Corrigan, B., French, J., Fullerton, T., Tensfeldt, T., \& Alzheimers Disease Working Group (2010). Disease progression meta-analysis model in Alzheimer's disease. Alzheimer's \& Dementia, 6(1), 39-53. doi: 10.1016/j.jalz.2009.05.665

Ivanoiu, A., Cooper, J. M., Shanks, M. F., \& Venneri, A. (2004). Retrieval of episodic and semantic autobiographical memories in early Alzheimer's disease and semantic dementia. Cortex, 40(1), 173-175. doi: 10.1016/S0010-9452(08)70939-0

Ivanoiu, A., Cooper, J. M., Shanks, M. F., \& Venneri, A. (2006). Patterns of impairment in autobiographical memory in the degenerative dementias constrain models of memory. Neuropsychologia, 44(10), 1936-1955. doi: 10.1016/j.neuropsychologia.2006.01.030 
Jahn, H. (2013). Memory loss in Alzheimer's disease. Dialogues in Clinical Neuroscience, 15(4), 445-454.

Karakaş, S., \& İrkeç, C. (2003). Alzheimer hastalığı kliniğinin nöropsikolojik profili [Neuropsychological profile of Alzheimer's disease]. Türkiye Klinikleri Nöroloji (Journal of Neurology), 1(1), 13-22.

Kirk, M., \& Berntsen, D. (2018). A short cut to the past: Cueing via concrete objects improves autobiographical memory retrieval in Alzheimer's disease patients. Neuropsychologia, 110, 113122. doi: 10.1016/j.neuropsychologia.2017.06.034

Kopelman, M. D., Wilson, B. A., \& Baddeley, A. D. (1989). The autobiographical memory interview: A new assessment of autobiographical and personal semantic memory in amnesic patients. Journal of Clinical and Experimental Neuropsychology, 11(5), 724-744. doi: 10.1080/01688638908400928

Kring, A. M., Johnson, S. L., Davison, G., \& Neale, J. (2012). Abnormal psychology: Late life and neurocognitive disorders. United States: Wiley Press.

Larsson, M., \& Willander, J. (2009). Autobiographical odor memory. Annals of the New York Academy of Sciences, 1170, 318-323. doi: 10.1111/j.1749-32.2009.03934.x

Larsson, M., Willander, J., Karlsson, K., \& Arshamian, A. (2014). Olfactory lover: Behavioral and neural correlates of autobiographical odor memory. Frontiers in Psychology, 5, 1-5. doi: 10.3389/ fpsyg.2014.00312

Levine, B., Svoboda, E., Hay, J. F., \& Winocur, G. (2002). Aging and autobiographical memory: Dissociationg episodic from semantic retrieval. Psychology and Aging, 17(4), 677-689. doi: 10.1037//08827974.17.4.677

Leyhe, T., Müller, S., Millian, M., Eschweiler, G. W., \& Saur, R. (2009). Impairment of episodic and semantic autobiographical memory in patients with mild cognitive impairment and early Alzheimer's disease. Neuropsychologia, 47(12), 2464-2469. doi: 10.1016/j.neuropsychologia.2009.04.018

Machado, S., Cunha, M., Minc, D., Portella, C. E., Velasques, B., Basile, L. F., Cagy, M., Piedade, R., \& Ribeiro, P. (2009). Alzheimer's disease and implicit memory. Arquivos de Neuro-Psiquiatria, 67, 334-342. doi: 10.1590/s0004-82x2009000200034

Martinelli, P., Anssens, A., Sperduti, M., \& Piolino, P. (2013). The influence of normal aging and Alzheimer's disease in autobiographical memory highly related to the self. Neuropsychology, 47(1), 69-78. doi: 10.1037/a0030453

Meeter, M., Eijsackers, E. V., \& Mulder, J. L. (2006). Retrograde amnesia for autobiographical memories and public events in mild and moderate alzheimer's disease. Journal of Clinical and Experimental Neuropsychology, 28, 914-927. doi: 10.1080/13803390591001043

Meulenbroek, O., Rijpkema, M., Kessels, R. P., Rikkert, M. G., \& Fernández, G. (2010). Autobiographical memory retrieval in patients with Alzhimer's disease. NeuroImage, 53(1), 331-340. doi: 10.1016/j. neuroimage.2010.05.082

Morris, R. G., \& Mograbi, D. C. (2013). Anosognosia, autobiographical memory and self knowledge in Alzheimer's disease. Cortex, 49, 1553-1565. doi: 10.1016/j.cortex.2012.09.006

Moses, A., Culpin, V., Lowe, C., \& McWilliam, C. (2004). Overgenerality of autobiographical memory in Alzheimer's disease. British Journal of Clinical Psychology, 43, 377-386.

Müller, S., Saur, R., Greve, B., Melms, A., Hautzinger, M., Fallgatter, A. J., \& Leyhe, T. (2012). Similar autobiographical memory impairment in long-term secondary progressive multiple sclerosis and Alzheimer's disease. Multiple Sclerosis Journal, 19(2), 225-232. doi: 10.1177/1352458512450352

Öktem, Ö. (2003). Alzheimer hastalığının erken, orta ve ileri dönemlerinde genel kognitif profil [Cognitive profile in the early, middle, and advanced stages of Alzheimer's disease]. In S. Karakaş, C. İrkeç \& N. Yüksel (Eds.), Beyin ve Nöropsikoloji [Brain and Neuropsychology] (pp. 101-111). Ankara: Çizgi Tıp Yayınevi.

Öner, S., \& Gülgöz, S. (2017). Autobiographical remembering regulates emotions: A functional perspective. Memory, 26(1), 15-28. doi: 10.1080/09658211.2017.1316510 
Pennanen, C., Kivipelto, M., Tuomainen, S., Hartikainen, P., Hänninen, T., Laakso, M. P., Hallikainen, M., Vanhanen, M., Nissinen, A., Helkala, E. -L., Vainio, P., Vanninen, R., Partanen, K., \& Soininen, H. (2004). Hippocampus and entorhinal cortex in mild cognitive impairment and early AD. Neurobiology of Aging, 25, 303-310. doi: 10.1016/S0197-4580(03)00084-8

Philippi, N., Botzung, A., Noblet, V., Rousseau, F., Despres, O., Cretin, B., Kremer, S., Blanc, F., \& Manning, L. (2015). Impaired emotional autobiographical memory associated with right amygdalar-hippocampal atrophy in Alzheimer's disease patients. Frontiers in Aging Neuroscience, 7. doi: $10.3389 /$ fnagi.2015.00021

Philippi, N., Noblet, V., Botzung, A., Despres, O., Renard, F., Sfikas, G., Cretin, B., Kremer, S., Manning, L., \& Blanc, F. (2012). MRI-based volumetry correlates of autobiographical memory in Alzheimer's disease. Plos One, 7(10). doi: 10.1371/journal.pone.0046200

Philippi, N., Roquet, D., Ben Malek, H., Noblet, V., Botzung, A., Cretin, B., \& Blanc, F. (2017). Henry, where have you lost your Self?. Cortex, 95, 37-50. doi: 10.1016/j.cortex.2017.06.019

Piefke, M., Weiss, P. H., Zilles, K., Markowitsch, H. J., \& Fink, G. R. (2003). Differential remoteness and emotional tone modulate the neural correlates of autobiographical memory. Brain, 126(3), 650-658. doi: 10.1093/brain/awg064

Piolino, P., Desgranges, B., Belliard, S., Matuszewski, V., Lalevee, C., De La Sayette, V., \& Eustache, F. (2003). Autobiographical memory and autonoetic consciousness: Triple dissociation in neurodegenerative diseases. Brain, 126, 2203-2219. doi: 10.1093/brain/awg222

Piolino, P., Desgranges, B., Clarys, D., Guiller-Girard, B., Taconnat, L., Isingrini, M., \& Eustache, F. (2006). Autobiographical memory, autonoetic consciousness, and self-perspective in aging. Psychology and Aging, 21(3), 510-525. doi: 10.1037/0882-7974.21.3.510

Prebble, S. C., Addis, D. R., \& Tippett, L. J. (2013). Autobiographical memory and sense of self. Psychological Bulletin, 139(4), 815-840. doi: 10.1037/a0030146

Rubin, D. C., Groth, E., \& Goldsmith, D. J. (1984). Olfactory cuing of autobiographical memory. The American Journal of Psychology, 97(4), 493-507.

Seidl, U., Lueken, U., Thomann, P. A., Geider, J., \& Schröder, J. (2011). Autobiographical memory deficits in Alzheimer's disease. Journal of Alzheimer's Disease, 27, 567-564. doi: 10.3233/JAD2011-110014

Serra, L., Bozzali, M., Fadda, L., De Simone, M. S., Bruschini, M., Perri, R., Caltagirone, C., \& Carlesimo, G. A. (2020). The role of hippocampus in the retrieval of autobiographical memories in patients with amnestic mild cognitive impairment due to Alzheimer's disease. Journal of Neuropsychology, 14, 46-68. doi: 10.1111/jnp.12174

Small, B. J., Fratiglioni, L., Viitanen, M., Winblad, B., \& Bäckman, L. (2000). The course of cognitive impairment in preclinical Alzheimer disease: Three- and 6-year follow-up of a population-based sample. Archives of Neurology, 57(6), 839-844. doi: 10.1001/archneur.57.6.839

Smith, A. P. R., Henson, R. N. A., Rugg, M. D., \& Dolan, R. J. (2005). Modulation of retrieval processing reflects accuracy of emotional source memory. Learning \& Memory, 12, 472-479. doi: $10.1101 / 1 \mathrm{~m} .84305$

Spaan, P. E. J., Raaijmakers, J. G. W., \& Jonker, C. (2003). Alzheimer's disease versus normal ageing: A review of the efficiency of clinical and experimental memorymeasures. Journal of Clinical and Experimental Neuropsychology, 25(2), 216-233. doi: 10.1076/jcen.25.2.216.13638

Svoboda, E., McKinnon, M., \& Levine, B. (2006). The functional neuroanatomy of autobiographical memory: A meta-analysis. Neuropsychologia, 44(12), 2189-2208. doi: 10.1016/j.neuropsychologia.2006.05.023

Tulving, E. (1972). Episodic and semantic memory. In E. Tulving \& W. Donaldson (Eds.), Organization of memory (pp. 381-402). United States: Academic Press. 
Tulving, E. (1985). Memory and consciousness. Canadian Psychology/Psychologie Canadienne, 26(1), 1-12. doi: 10.1037/h0080017

Tulving, E. (1999). On the uniqueness of episodic memory. In L. G. Nilsson \& H. J. Markowitsch (Eds.), Cognitive neuroscience of memory (pp. 11-42). Göttingen: Hogrefe \& Hubner Publishers.

Tulving, E. (2002). Episodic memory: From mind to brain. Annual Review of Psychology, 53, 1-25. doi: 10.1146/annurev.psych.53.100901.135114

Turkish Statistical Institute. (2018). Elderly statistics 2018. https://biruni.tuik.gov.tr/yayin/views/ visitorPages/yayinGoruntuleme.zul?yayin_no=474

Uçar-Boyraz, F., \& Er, N. (2007). Alzheimer ve depresyon tanılı gruplar ile normal örneklemde, kişisel ve toplumsal olaylara ilişkin otobiyografik bellek özellikleri [Autobiographical memories for personal and public events in Alzheimer's disease, depression, and healthy individuals]. Turkish Journal of Psychology, 22(60), 45-64.

Velayudhan, L. (2015). Smell identification function and Alzheimer's disease: A selective review. Current Opinion in Psychiatry, 28(2), 173-179. doi: 10.1097/YCO.0000000000000146

Willander, J., \& Larsson, M. (2006). Smell your way back to childhood: Autobiographical odor memory. Psychonomic Bulletin \& Review, 13, 240-244. doi: 10.3758/BF03193837

Williams, H. L., \& Conway, M. A. (2009). Networks of autobiographical memories. In P. Boyer \& J. Wertsch (Eds.), Memory in Mind and Culture (pp. 33-61). New York: Cambridge Psychology Press.

World Health Organization. (2019, September 19). Dementia: Key facts. Retrieved from https://www. who.int/news-room/fact-sheets/detail/dementia1 
